\title{
Pembuatan sistem informasi inventarisasi tanaman berbasis QR code untuk identifikasi tanaman Taman Hutan Kota HM
} Sabki Kota Jambi

\section{Ulfa Khaira*, Tri Suratno, Mauladi, Reni Aryani, \& Edi Saputra}

Fakultas Sains dan Teknologi, Universitas Jambi, Indonesia

\section{*ulfa.ilkom@gmail.com}

\begin{abstract}
The Urban Forest of HM Sabki has great potential as a tourist destination, not only as a recreation area but also as a center for research and plant conservation. For this reason, the Urban Forest of HM Sabki is expected to be able to provide adequate information about its plants. This community service program creates a plant inventory information system and QR code as a marker of plants that can be scanned using a smartphone. This technology enables visitors to access detailed information about plants. QR code is a printed 2dimensional image code that can store data. This technology can display information about plants that have been previously entered by the manager into the plant inventory information system. Through this application, the Urban Forest management can easily manage all information about plants.
\end{abstract}

Absrak Taman Hutan Kota HM Sabki mempunyai potensi yang besar sebagai destinasi tujuan wisata, tidak hanya sebagai tempat rekreasi tetapi juga sebagai pusat penelitian dan konservasi tanaman. Untuk itu, Taman Hutan Kota HM Sabki diharapkan mampu menyediakan informasi yang memadai mengenai tanamannya. Program pengabdian pada masyarakat (PPM) ini membuat sistem informasi inventarisasi tanaman dan QR code sebagai penanda tanaman yang dapat dipindai menggunakan smartphone. Dengan begitu pengunjung dapat mengakses informasi detail mengenai tanaman. QR code adalah kode gambar 2dimensi tercetak yang dapat menyimpan sejumlah informasi. Teknologi ini dapat menampilkan informasi mengenai tanaman yang sebelumnya telah dimasukkan oleh pengelola ke sistem informasi inventarisasi tanaman. Melalui aplikasi ini pengelola dapat dengan mudah mengelola semua informasi tentang tanaman.

Keywords: information system; plant inventory; QR code; urban forest

\section{O OPEN ACCESS}

Citation: Khaira, U., Suratno, T., Mauladi, Aryani, R., \& Saputra, E. (2020). Pembuatan sistem informasi inventarisasi tanaman berbasis QR code untuk identifikasi tanaman Taman Hutan Kota HM Sabki Kota Jambi. Riau Journal of Empowerment, 3(2), 69-78. https://doi.org/10.31258/raje.3.2.69-78

Paper type: Community service

Received: 2019-07-23 Revised: 2020-04-01 Accepted: 2020-06-11

Language: Bahasa Indonesia (id)

Funding: Kegiatan Pengabdian kepada Masyarakat ini mendapat bantuan dana PNBP Fakultas Sains dan Teknologi, Universitas Jambi Tahun Anggaran 2018 (Nomor: SP DIPA042.01.2.400950/2018) sesuai Surat Perjanjian Penugasan dalam rangka pelaksanaan Pengabdian Kepada Masyarakat Nomor: 1346/UN21.17/PM/2018 tanggal 23 April 2018

ISSN 2623-1549 (online), 2654-4520 (print)

(C) 2020 Ulfa Khaira et al. Author(s) retain the copyright of article published in this journal, with first publication rights granted to Riau Journal of Empowerment. The article is licenced under Creative Commons Attribution 4.0 International License. This license permits unrestricted use, distribution, and reproduction in any medium, provided the original author and source are credited. 


\section{PENDAHULUAN}

Di kota Jambi terdapat beberapa Ruang Terbuka Hijau (RTH) sebagai paru-paru kota, salah satunya adalah Taman Hutan Kota HM Sabki yang terletak di Kelurahan Kenali Asam Bawah Kecamatan Kota Baru. Taman Hutan Kota HM Sabki dinamakan demikian sebagai apresiasi Pemerintah Kota Jambi atas jasa dan perjuangan mantan Walikota Jambi HM Sabki yang telah merintis pengembangannya sejak tahun 1987, dari semula berupa kebun karet tua yang secara bertahap dilakukan rehabilitasi dan penanaman berbagai tanaman langka. Visi Taman Hutan Kota HM Sabki adalah "Terwujudnya hutan kota menjadi pusat pelestarian keanekaragaman hayati yang mampu menciptakan iklim mikro guna menjaga keseimbangan dan menjadi pusat pendidikan berbasis lingkungan yang lestari”.

Sebagai pusat pelestarian keanekaragaman hayati Taman Hutan Kota HM Sabki saat ini memiliki kurang lebih 187 jenis tanaman dan akan terus bertambah koleksinya. Terdapat beberapa jenis pohon yang telah tumbuh secara alami, diantaranya Gaharu, Sindur, Pinang Hutan, Durian Hutan, dan lain-lain. Taman Hutan Kota HM Sabki memiliki potensi yang sangat besar sebagai kawasan wisata yang tidak hanya digunakan sebagai tempat rekreasi, tetapi juga sebagai pusat pelestarian plasma nutfah, pengawetan keanekaragaman jenis tumbuhan dan satwa beserta ekosistemnya serta budidaya hasil hutan bukan kayu dan pusat pemeliharaan berbagai macam tanaman. Oleh karena itu, Taman Hutan Kota HM Sabki diharapkan dapat menyediakan informasi yang memadai mengenai tanaman yang ada bagi para pengunjungnya. Pengelola taman hutan kota telah menyediakan plang tanaman, akan tetapi hanya memuat nama lokal dan nama latin tanaman. Dengan plang konvensional ini pengunjung tidak mendapatkan banyak informasi mengenai tanaman (Ishak et al., 2013).

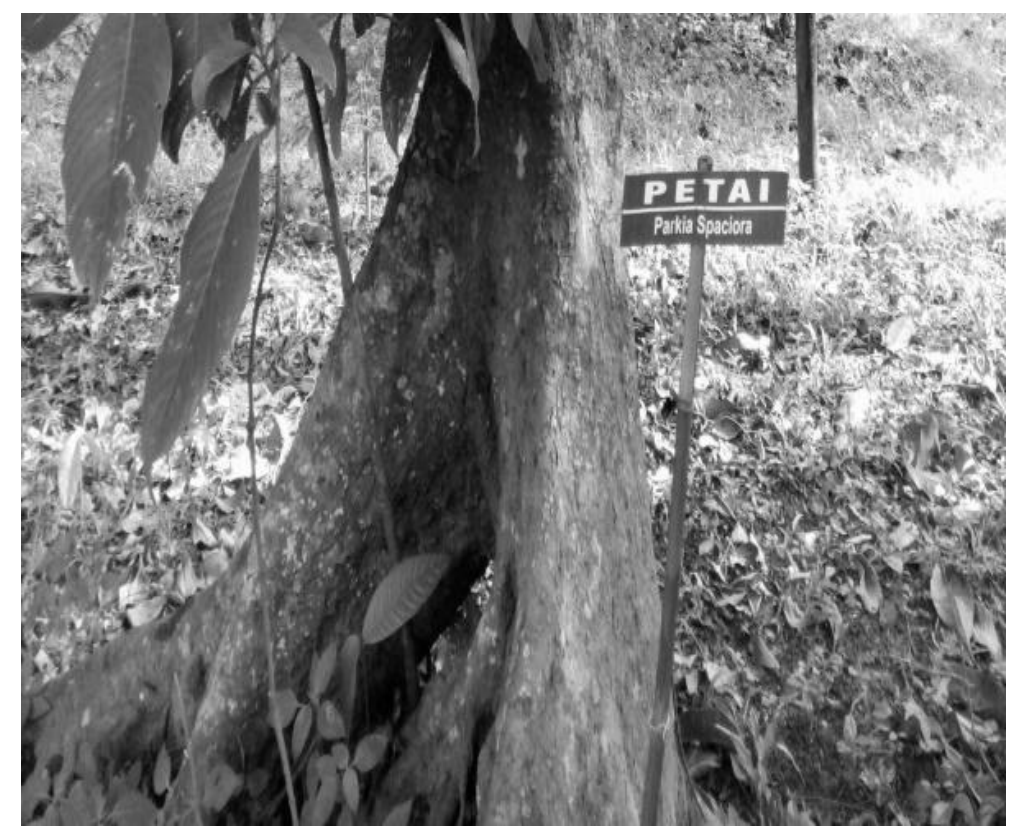

Gambar 1. Tanaman dengan plang konvensional

Agar tujuan tersebut dapat tercapai, dibutuhkan manajemen pengelolaan yang baik. Selama ini Dinas Lingkungan Hidup Kota Jambi menyimpan data tanaman secara manual dalam buku catatan dan file di komputer yang memiliki peluang besar untuk hilang. Salah satu upaya untuk menyelesaikan permasalahan ini adalah dengan memanfaatkan Teknologi Informasi yaitu dengan mengembangkan Website Sistem Informasi Inventarisasi Tanaman berbasis Quick Response (QR) code. Data tanaman dari Sistem Informasi Inventarisasi Tanaman digunakan 
untuk penandaan atau pelabelan tanaman dengan menggunakan teknologi QR code, pengunjung cukup memindai label $\mathrm{QR}$ code kemudian akan dialihkan ke alamat Uniform Resource Locator (URL) halaman website Sistem Informasi Inventarisasi Tanaman sehingga pengunjung mendapatkan informasi detail mengenai tanaman, selain itu juga dapat memudahkan pihak pengelola untuk memonitor data koleksi yang ada di taman hutan kota HM Sabki (Masalha \& Hirzallah, 2014).

QR code ini adalah kode gambar 2 dimensi tercetak yang dapat menyimpan sejumlah informasi (Law \& So, 2010). QR code ini dapat menyimpan informasi mengenai identitas suatu tanaman dalam bentuk yang ringkas dan sederhana dan dapat dibaca dengan mudah oleh pengunjung menggunakan smartphone berkamera (Qian et al., 2015). Implementasi QR code yang akan digunakan di Taman Hutan Kota HM Sabki berupa plang khusus yang akan melengkapi plang nama yang sudah ada. Artinya, dapat diletakkan bersisian dengan plang nama yang sudah ada. QR code tersebut dapat dicetak menggunakan berbagai macam media selain plang yang terbuat dari besi, misalnya stiker yang terbuat dari plastik. Pengunjung nantinya dapat memindai QR code menggunakan smartphone atau perangkat mobile lainnya yang sudah dilengkapi dengan fasilitas kamera. Namun sebelum itu, perlu ditambahkan aplikasi pemindai ke dalam alat tersebut, yang berfungsi sebagai penerjemah QR code yang telah dipindai tadi. Untuk beberapa perangkat, aplikasi tersebut sudah terintegrasi tanpa perlu menambahkan secara manual. Dengan adanya QR code ini, pengunjung dapat memperoleh lebih banyak informasi selain yang didapat dari plang nama konvensional.

Ishak et al. (2013) membuat aplikasi pelabelan tanaman berbasis QR code untuk data tanaman di Sultan Idris Shah Forest Education Center, aplikasi ini berjalan dengan baik, pengunjung dapat memindai label QR code pada tanaman dengan menggunakan smartphone dan mendapatkan informasi detail mengenai tanaman. Namun data tidak dapat diakses jika tidak ada koneksi internet.

Pengabdian pada masyarakat ini bertujuan untuk membuat Website Sistem Informasi Inventarisasi Tanaman berbasis QR code yang memudahkan pihak Dinas Lingkungan Hidup dalam mengelola data tanaman yang dapat diakses melalui komputer atau smartphone, kemudian QR code akan membuat informasi tersebut dapat diakses oleh pengunjung. Meskipun pengunjung tidak memiliki akses internet, pengunjung masih bisa mendapat informasi dasar mengenai taksonomi tanaman tersebut.

\section{METODE}

\section{Survei dan Diskusi}

Kegiatan Diskusi dilakukan antara tim pelaksana pengabdian dengan pihak Dinas Lingkungan Hidup, dimaksudkan untuk membicarakan permasalahan yang dimiliki, harapan dan keinginan mitra dalam pemanfaatan IPTEK, langkah-langkah yang akan dilakukan, dan jadwal pelaksanaan pendampingan yang akan dilakukan pada kegiatan pengabdian.

Pada kegiatan ini juga dilakukan analisa terhadap sistem yang sudah ada dengan tujuan untuk memahami proses bisnis dari layanan informasi pada kedua mitra. Studi kelayakan diperlukan untuk mengetahui memadai atau tidaknya sumberdaya yang dimiliki mitra yang akan dipergunakan pada fase-fase pengembangan selanjutnya. 


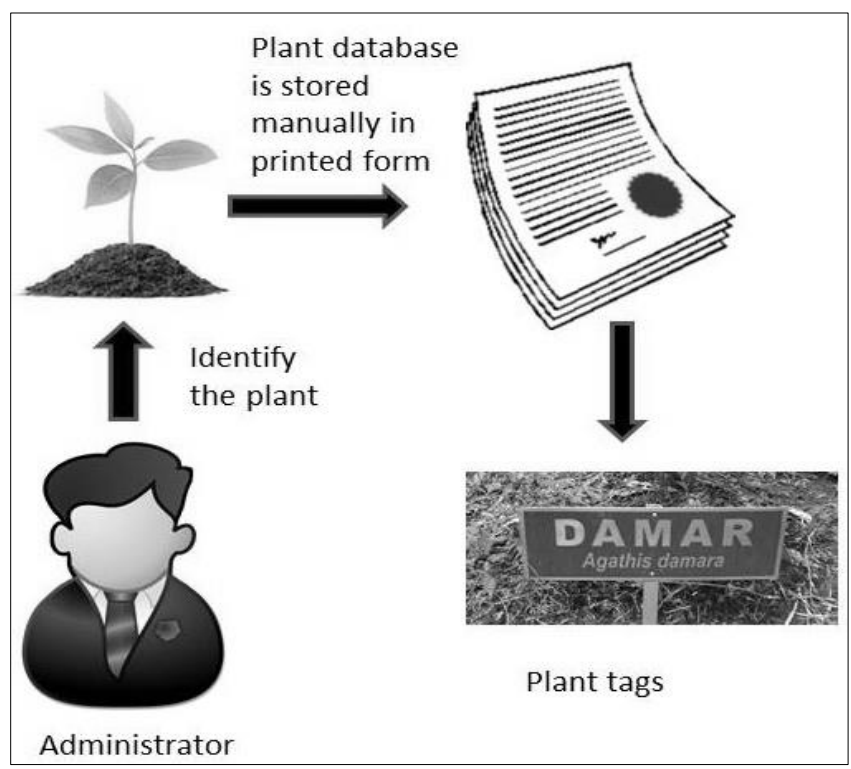

Gambar 2. Proses penyimpanan data secara konvensional

Gambar 2 menunjukkan sistem yang saat ini berjalan, dimana staf Dinas Lingkungan Hidup melakukan identifikasi tanaman kemudian mencatat dan menyimpan data secara manual ke dalam buku, selanjutnya membuat plang data tanaman. Dengan cara seperti ini besar kemungkinan data akan hilang. Sehingga kami menawarkan website Sistem Informasi Inventarisasi Tanaman berbasis QR code untuk menjawab permasalahan tersebut (Gambar 3). Administrator dapat mengelola data tanaman di satu tempat yaitu database tanaman, data yang disimpan berupa gambar, posisi koordinat tanaman, umur, informasi taksonomi, serta manfaat tanaman. Untuk mengakses informasi, pengunjung terlebih dahulu meng-install aplikasi pemindai QR code.

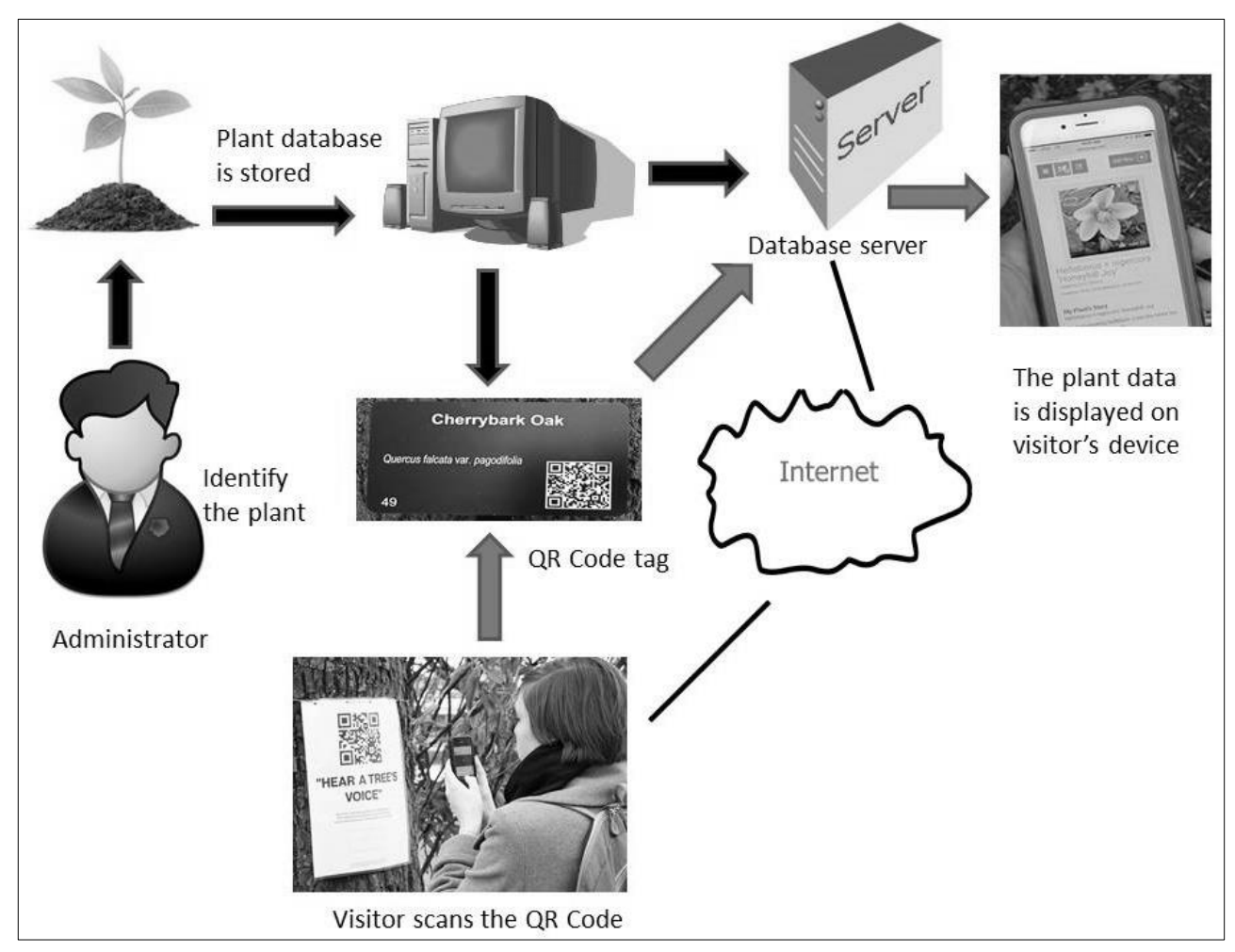

Gambar 3. Rancangan sistem yang ditawarkan 


\section{Desain Website Sistem Informasi Inventarisasi Tanaman Berbasis QR Code}

Proses bisnis sistem digambarkan dengan use case diagram. Use case diagram menunjukan peranan dari bermacam-macam pengguna dan cara pengguna tersebut dalam berinteraksi dengan sistem (Scott, 2001). Terdapat dua aktor dan empat aktivitas utama pada use case yang ditunjukkan Gambar 4. Aktor staf Dinas Lingkungan Hidup bertindak sebagai administrator memiliki aktivitas utama yaitu mengelola data spesies, mengelola data pohon, use case mengelola data spesies mempunyai hubungan include dengan use case login. Untuk melakukan aktivitas pengelolaan data spesies administrator harus login terlebih dahulu.

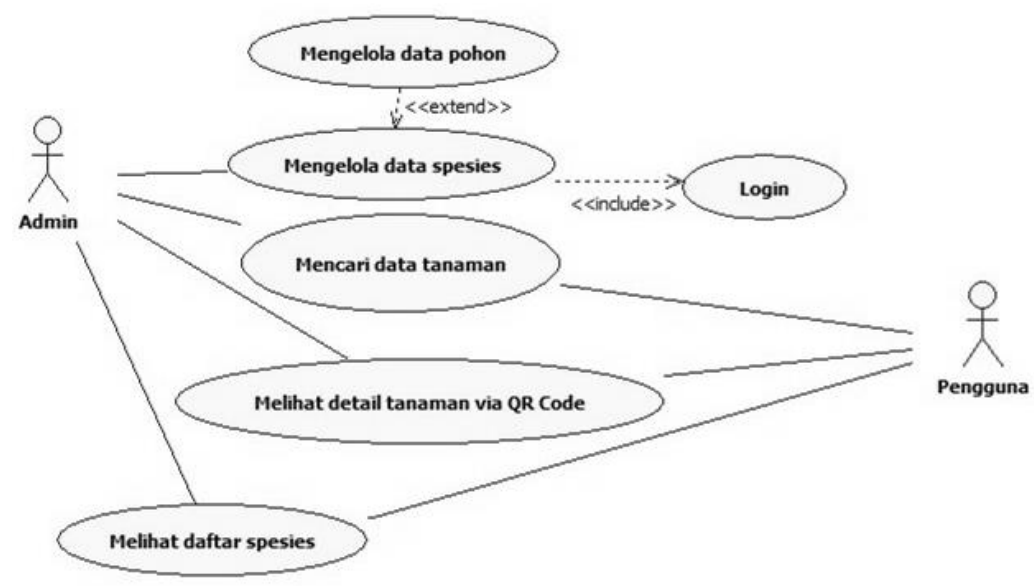

Gambar 4. Use case diagram Sistem Informasi Inventarisasi Tanaman

Perancangan basis data digambarkan dengan menggunakan class diagram. Class diagram menunjukan hubungan antar kelas serta struktur dan deskripsi kelas. Selain itu juga menunjukkan bagaimana entitas yang berbeda (orang, benda, dan data) saling berhubungan (Satzinger et al., 2011). Pada sistem ini terdapat empat kelas utama, yaitu: kelas user, species, trees, dan kontak. Class diagram Sistem Informasi Inventarisasi Tanaman dapat dilihat pada Gambar 5.

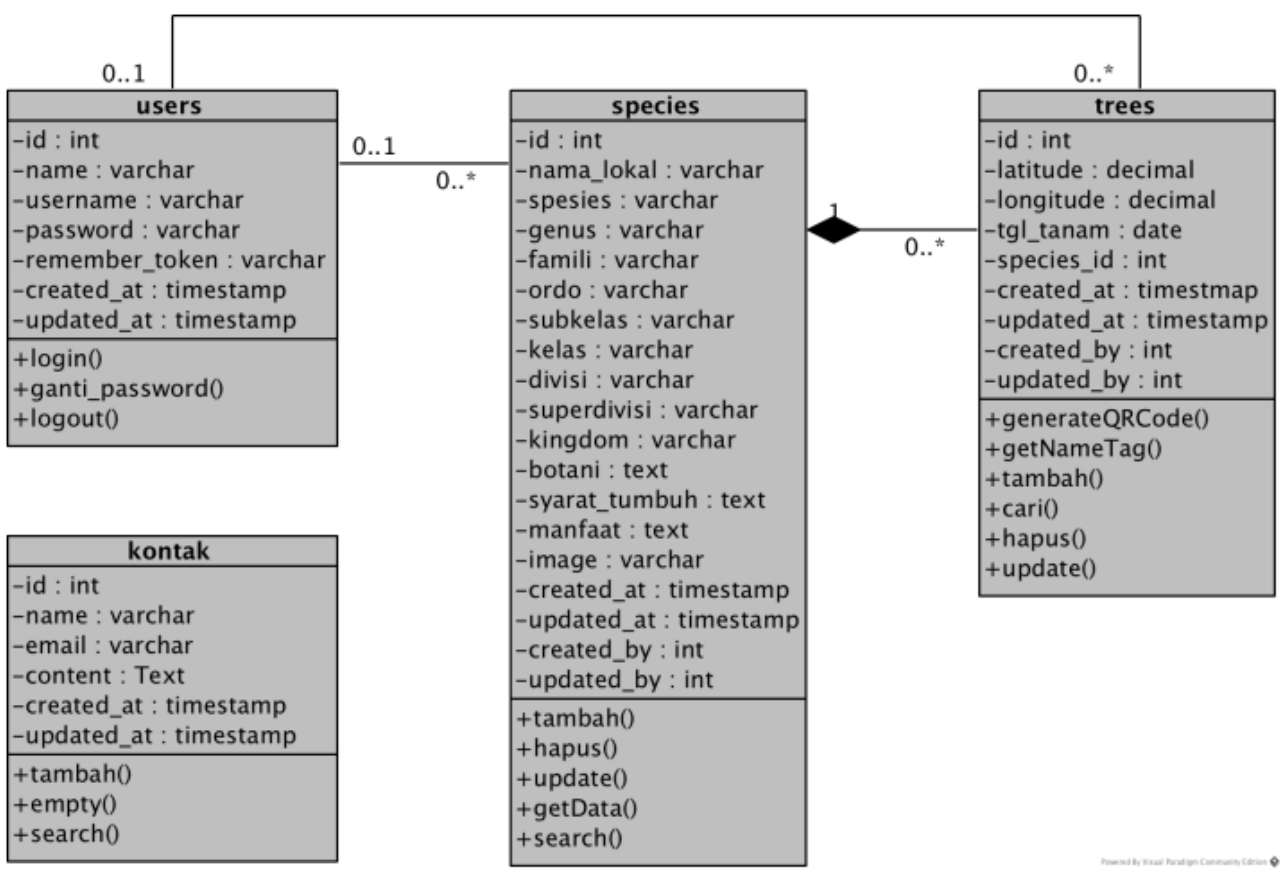

Gambar 5. Class diagram sistem informasi inventarisasi tanaman 


\section{Pembangunan Website Sistem Informasi Inventarisasi Tanaman Berbasis QR Code}

Pembangunan Website Sistem Informasi Inventarisasi Tanaman Berbasis QR Code membutuhkan pengetahuan teknis dari ilmu komputer dan ilmu kehutanan. Dalam pengabdian ini data didapatkan dari survei tanaman yang dilakukan oleh Dinas Lingkungan Hidup. Datadata ini direkam dan disimpan pada database yang dijalankan Server MySQL. ID tanaman dikonversi menjadi QR Code yang akan dicetak dan ditandai pada tanaman. Sistem ini diimplementasikan menggunakan bahasa pemrograman php dengan framework laravel 5.4 dan MySQL sebagai basis data.

\section{Pelatihan Mengelola Website Sistem Informasi Inventarisasi Tanaman Berbasis QR Code}

Program yang telah selesai dibuat, selanjutnya diperkenalkan dan dilakukan pelatihan untuk dioperasikan oleh mitra. Pada tahap ini pelatihan pengoperasian sistem informasi dilakukan baik secara tertulis maupun praktek. Pada tahap ini juga dilakukan evaluasi kemampuan mitra dalam mengelola Website Sistem Informasi Inventarisasi Tanaman Berbasis QR Code, dengan melihat hasil tugas yang diberikan.

\section{Sosialisasi Kepada Masyarakat}

Tim pengabdian bersama mitra melakukan sosialisasi kepada masyarakat dalam menggunakan Website Sistem Informasi Inventarisasi Tanaman Berbasis QR Code untuk identifikasi tanaman.

\section{HASIL DAN PEMBAHASAN}

\section{Kegiatan Pelatihan Mengelola Website Sistem Informasi Inventarisasi Tanaman Berbasis QR Code bagi staff di Dinas Lingkungan Hidup Kota Jambi}

Kegiatan pelatihan mengelola Website Sistem Informasi Inventarisasi Tanaman bagi staf di Dinas Lingkungan Hidup Kota Jambi dilaksanakan pada tanggal 31 Agustus 2018 bertempat di Aula Adiwiyata Dinas Lingkungan Hidup Kota Jambi. Kegiatan ini diikuti oleh 15 orang peserta.

Pada kegiatan ini dipaparkan bagaimana mengelola Website Sistem Informasi Inventarisasi Tanaman. Hasil yang diperoleh pada kegiatan ini adalah pemahaman dari para peserta mengenai materi yang disampaikan. Bagi pengguna umum dapat memanfaatkan sistem informasi ini untuk melihat informasi koleksi tanaman yang ada di Hutan Kota HM Sabki. Dan bagi administrator teknologi informasi (IT) Dinas Lingkungan Hidup Kota Jambi dapat memanfaatkan sistem informasi ini untuk menyimpan dan mengelola data koleksi tanaman.

Setiap peserta dibagikan modul petunjuk penggunaan Sistem Informasi Inventarisasi Tanaman Hutan Kota HM Sabki. Peserta diajak untuk mencoba langsung menggunakan sistem informasi ini, termasuk administrator IT Dinas Lingkungan Hidup Kota Jambi dilatih untuk mengelola database sistem informasi (Gambar 6). 


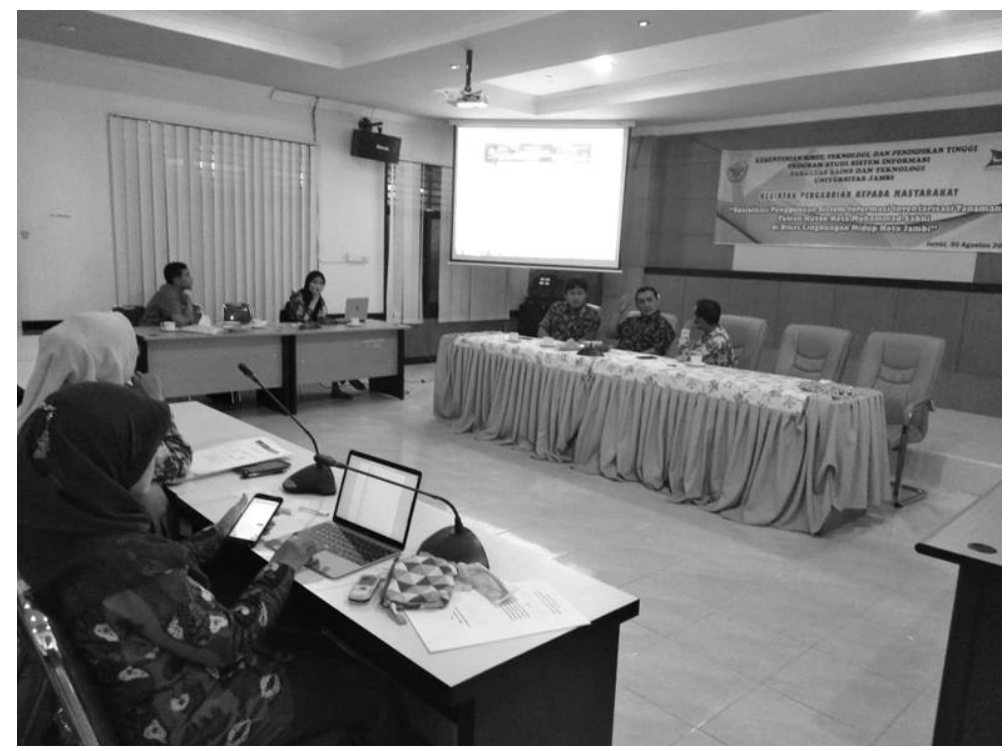

Gambar 6. Penyampaian materi

Dari hasil tugas yang diberikan kepada administrator, hampir $90 \%$ tugas dapat dikerjakan. Hal ini menunjukan bahwa website Sistem Informasi Inventarisasi Tanaman mudah digunakan.

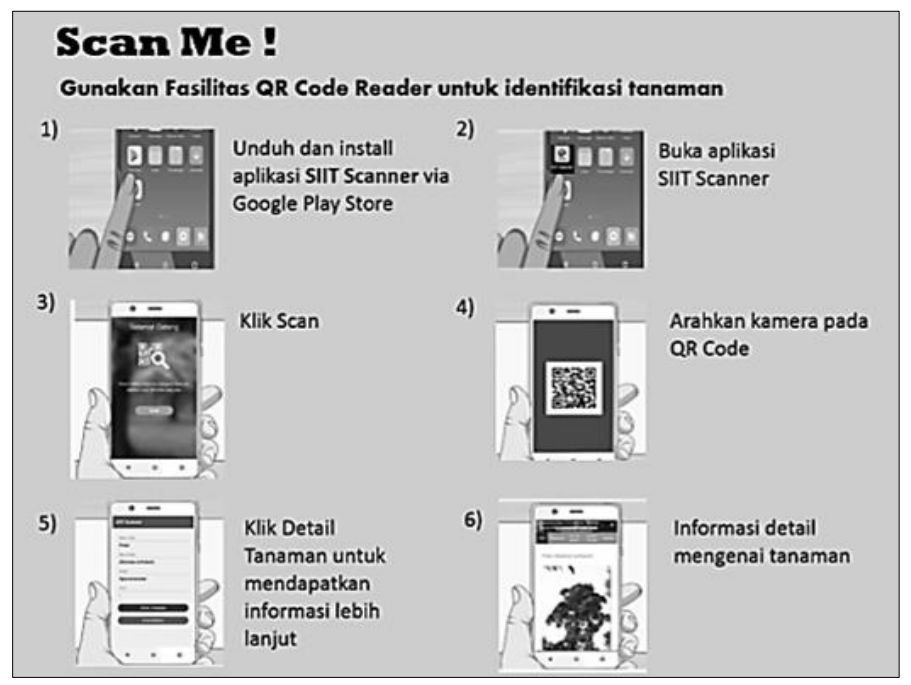

Gambar 7. Petunjuk penggunaan QR Code

\section{Kegiatan Sosialisasi Pemanfaatan Teknologi QR Code untuk Identifikasi Tanaman bagi Pengunjung Taman Hutan Kota HM Sabki}

Kegiatan ini dilaksanakan bertempat di Taman Hutan Kota HM Sabki. Kegiatan ini diikuti oleh 14 orang peserta. Pada kegiatan ini disosialisasikan bagaimana menggunakan teknologi QR Code untuk mengidentifikasi tanaman yang ada di Taman Hutan Kota HM Sabki. Pengunjung dapat memindai QR Code menggunakan smartphone atau perangkat mobile lainnya yang sudah dilengkapi dengan fasilitas kamera. Namun sebelum itu, perlu ditambahkan aplikasi pemindai ke dalam alat tersebut, yang berfungsi sebagai penerjemah QR Code yang telah dipindai tadi. Pengunjung diajak untuk menginstall Aplikasi SIIT Scanner yang dapat diunduh di Play Store. Petunjuk penggunaan QR Code dapat dilihat pada Gambar 7. 


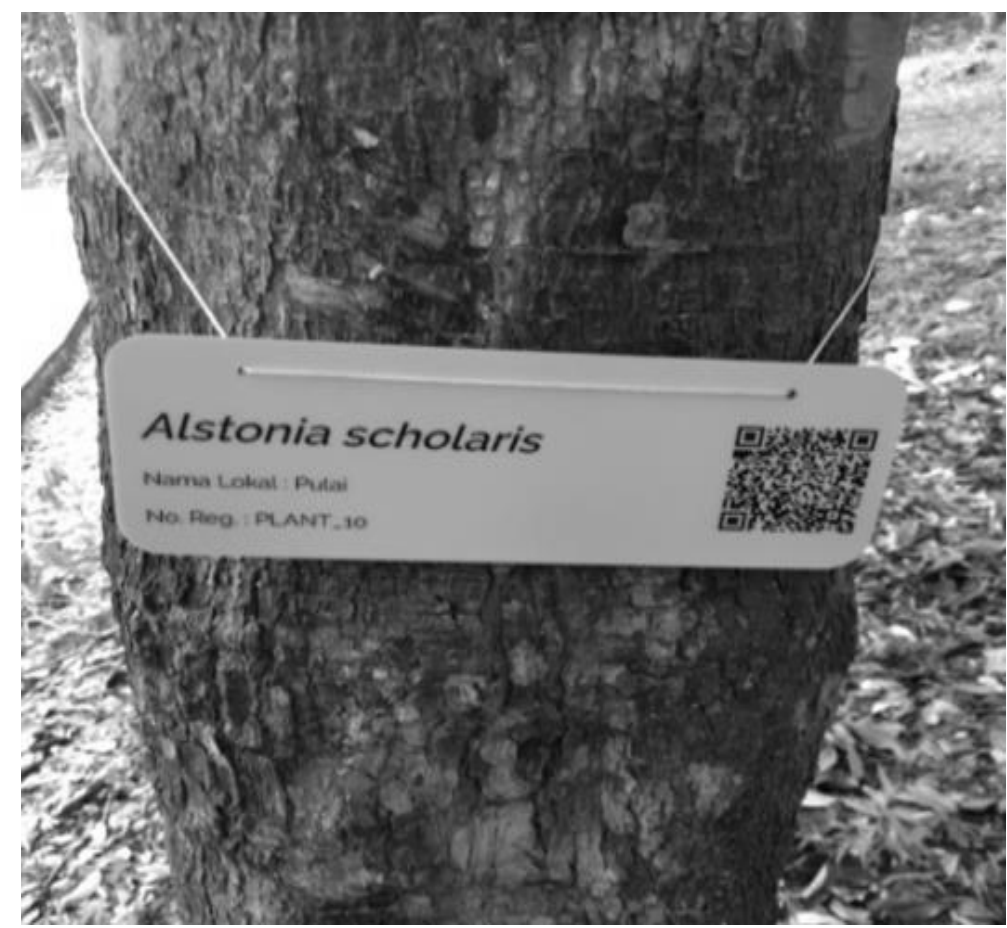

Gambar 8. Plang QR Code

Setelah meng-install aplikasi SIIT Scanner, pengunjung diajak untuk memindai QR Code yang sudah terpasang di badan pohon (Gambar 8). Dengan adanya QR Code ini, pengunjung dapat memperoleh lebih banyak informasi selain yang didapat dari plang nama konvensional (Gambar 9).
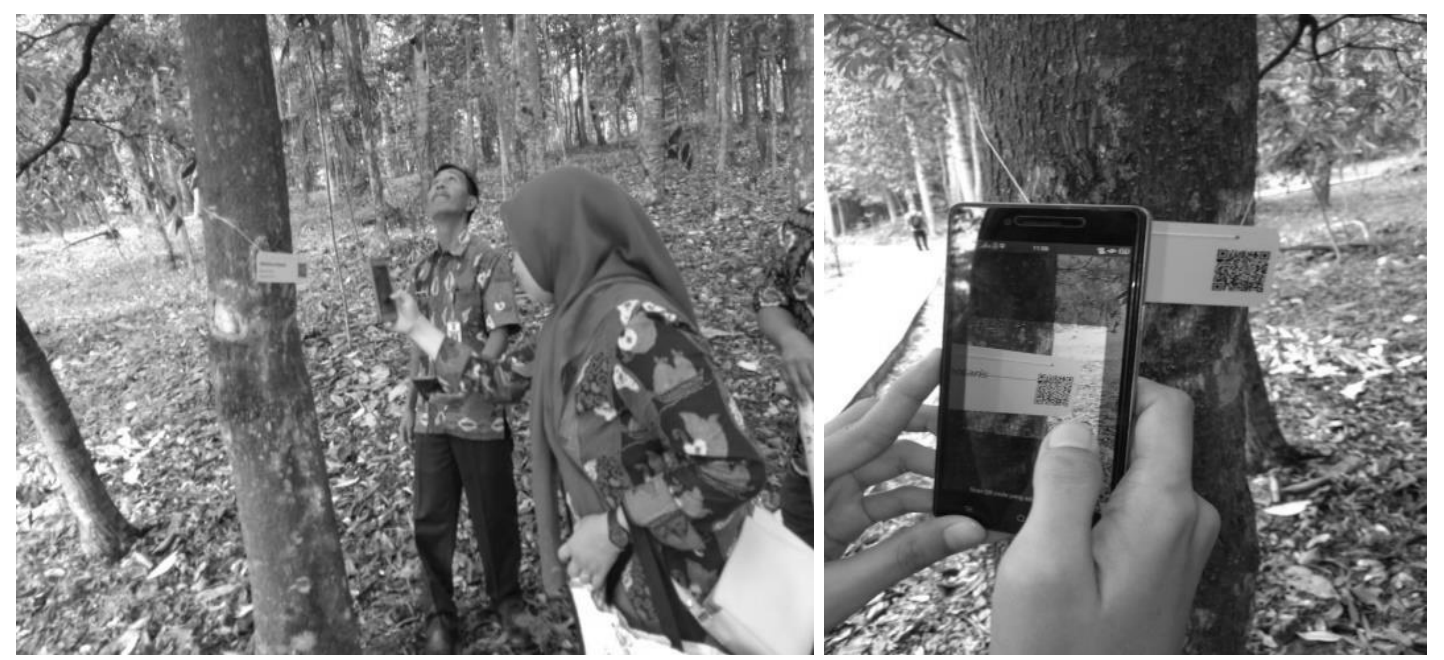

Gambar 9. Pengunjung memindai QR Code

Pada plang tanaman terdapat informasi nama ilmiah, nama lokal, nomor registrasi pohon dan label QR Code yang dapat dipindai untuk mendapatkan informasi detail mengenai tanaman. Aplikasi SIIT Scanner dapat digunakan dalam kondisi offline maupun online. 


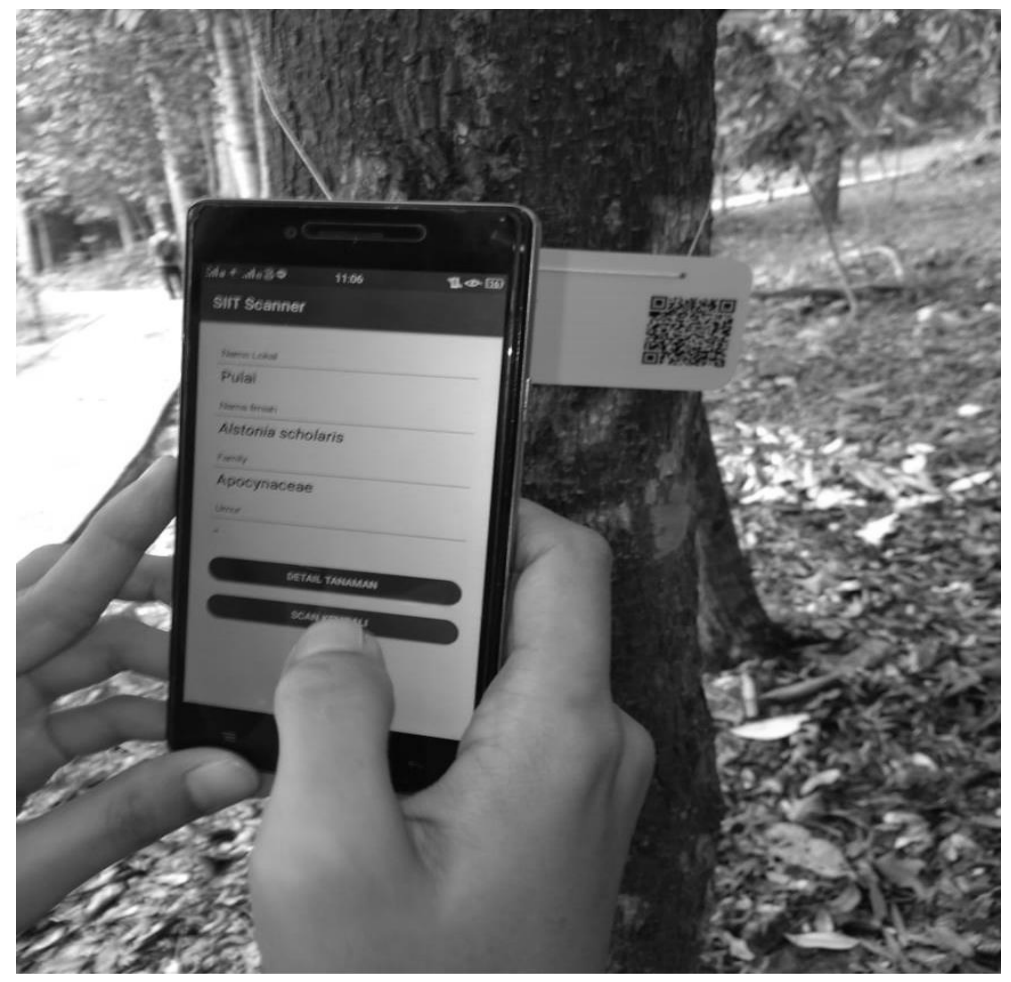

Khaira et al.

Gambar 10. Hasil pindai pada kondisi offline

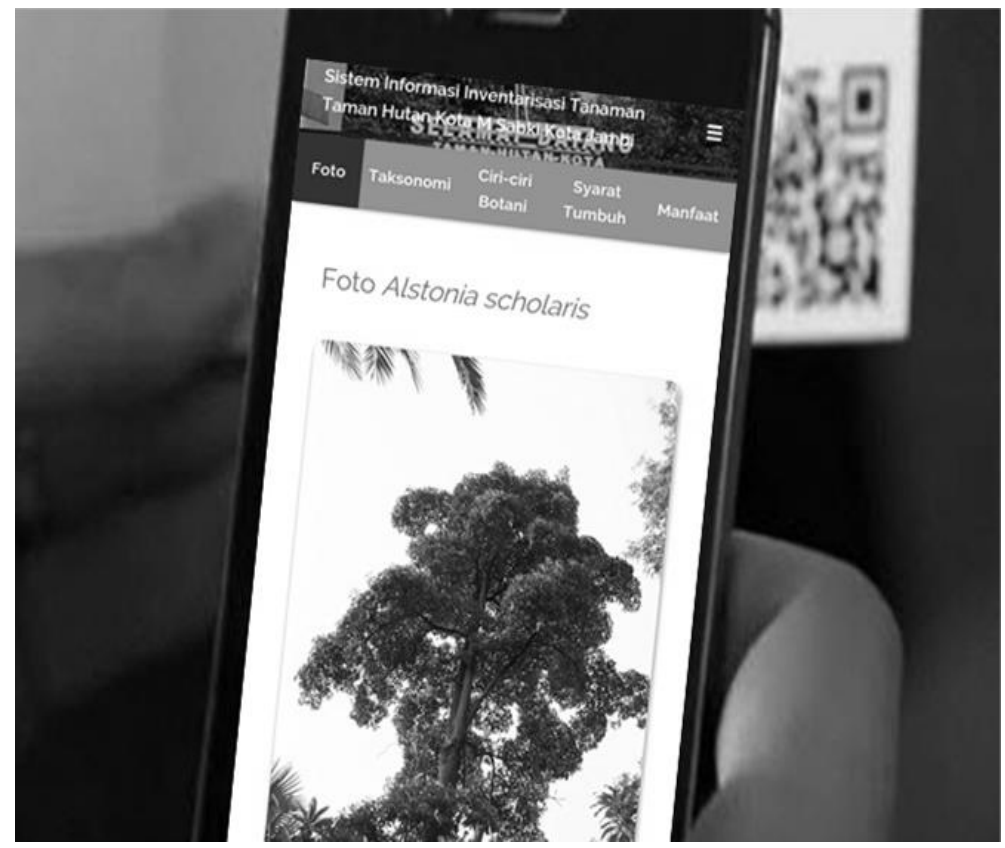

Gambar 11. Informasi detail tanaman

Pada saat offline aplikasi ini dapat menampilkan informasi pohon yang meliputi nama lokal, nama ilmiah, family, dan umur (Gambar 10). Jika koneksi internet tersedia, pengunjung dapat melihat informasi detail mengenai pohon dengan mengetuk tombol DETAIL TANAMAN, maka akan terhubung langsung dengan Website Sistem Informasi Inventarisasi Tanaman dengan alamat https://siitdlh.jambikota.go.id (Gambar 11). 


\section{KESIMPULAN}

Kegiatan pengabdian ini memperoleh antusiasme yang besar baik dari staf Dinas Lingkungan Hidup maupun dari masyarakat pada umumnya. Melalui Kepala Dinas Lingkungan Hidup Kota Jambi, Walikota Jambi memberikan apresiasi kepada Tim Pengabdi.

Secara umum kegiatan pengabdian ini telah berhasil dilaksanakan dengan baik. Hal ini terbukti dari tercapainya luaran yang diharapkan, yaitu berupa Website Sistem Informasi Inventarisasi Tanaman Berbasis QR Code dan aplikasi pemindai SIIT Scanner. Website dan aplikasi pemindai memberi nilai tambah bagi pengunjung Taman Hutan Kota HM Sabki. Pengunjung mendapatkan pengalaman baru menggunakan teknologi yang ramah pengguna. Pengunjung juga dengan mudah mendapatkan informasi yang lengkap mengenai koleksi tanaman. Selain memberi nilai tambah bagi pengunjung, kegiatan pengabdian ini memberi manfaat kepada pengelola Taman Hutan Kota HM Sabki. Kegiatan ini memberi kemampuan baru kepada pihak administrator Teknologi Informasi Dinas Lingkungan Hidup Kota Jambi mengelola sistem informasi inventarisasi tanaman.

\section{UCAPAN TERIMA KASIH}

Kegiatan Pengabdian kepada Masyarakat ini mendapat bantuan dana PNBP Fakultas Sains dan Teknologi, Universitas Jambi, Tahun Anggaran 2018 (Nomor: SP DIPA-042.01.2.400950 12018) sesuai Surat Perjanjian Penugasan dalam rangka pelaksanaan Pengabdian Kepada Masyarakat Nomor: 1346/UN21.17/PM/2018 tanggal 23 April 2018. Ucapan terima kasih disampaikan kepada Fakultas Sains dan Teknologi Universitas Jambi dan Dinas Lingkungan Hidup Kota Jambi yang telah memberikan dukungan peralatan dan fasilitas yang diperlukan.

\section{Daftar Pustaka}

1. Ishak, I., Sidi, F., Affendey, L. S., Sani, N. F. M., Hamzah, A. S., \& Bawon, P. (2013). Mobile Plant Tagging System for Urban Forest Eco-Tourism Using QR Code. Paper presented at 2013 International Conference on Advanced Computer Science Applications and Technologies, Kuching, Malaysia, https://doi.org/10.1109/ACSAT.2013.15

2. Law, C., \& So, S. (2010). QR Codes in Education. Journal of Educational Technology Development and Exchange (JETDE), 3(1), 7. https://doi.org/10.18785/jetde.0301.07

3. Masalha, F., \& Hirzallah, N. (2014). A Students Attendance System Using QR Code. International Journal of Advanced Computer Science and Applications, 5(3), 75-79. http://doi.org/10.14569/IJACSA.2014.050310

4. Satzinger, J. W., Jackson, R. B., \& Burd, S. D. (2011). Systems analysis and design in a changing world. Cengage learning.

5. Scott, K. (2001). UML explained. Addison-Wesley Professional.

6. Qian, J. P., Yang, X. T., Wu, X. M., Xing, B., Wu, B. G., \& Li, M. (2015). Farm and environment information bidirectional acquisition system with individual tree identification using smartphones for orchard precision management. Computers and Electronics in Agriculture, 116, 101-108. https://doi.org/10.1016/j.compag.2015.06.003 